Denis Petrina

\title{
KŪNIŠKOS MEDIACIJOS: BIOMEDIJOS ŠIUOLAIKINĖJE KONTROLĖS VISUOMENĖJE
}

Lietuvos kultūros tyrimu institutas Saltoniškių g. 58, LT-08105 Vilnius El.paštas: denisas.duce@gmail.com

Šio straipsnio tikslas yra pristatyti, išsamiai aptarti ir kritiškai reflektuoti palyginus naują ir aktualų biomedijų konceptą, leidžiantị panaikinti (tariamą) dichotomiją tarp technologijų ir kūno. Pačia bendriausia prasme, biomedijos yra apibrěžtinos kaip toks medijavimo būdas, kai medijos tiesiogiai veikia biologinę kūno dimensiją, transformuodamos ją, ir vice versa. Straipsnio pradžioje pristatomas biomedijų radimosi kontekstas - kontrolès visuomenès (Gilles'is Deleuze’as). Pirmoje dalyje apžvelgiama biomedijų sampratos genezè bei aptariamos dvi biomedijų konceptualizavimo paradigmos - epistemologinè („tamsiųjų medijų“ (Eugene’as Thackeris)) ir etinė („pilkųjų medijų“ (Matthew Fulleris, Andrew Goffey)). Antroje straipsnio dalyje išryškinamas biomedijų santykis su kiberbiopolitiniu režimu ir aptariama ypatinga, veikianti per biomedijas biogalios forma - neurogalia (Warrenas Neidichas). Galiausiai, paskutinejje dalyje yra svarstomos dvi galimos pasipriešinimo neigiamam biomediju poveikiui linijos: negatyvi ir kritinè.

RAKTAŽODŽIAI: biomedijos, „tamsiosios medijos“, „pilkosios medijos“, biopolitika, kontrolè. 


\section{Ikontekstinant biomedijas: kontrolè ir / kaip biopolitika}

Paradigmine tapusioje medijų studijose esè „Prierašas apie kontrolès visuomenes“ Gilles'is Deleuze’as aprašo naująją galios simptomatiką, kurią pavadina „kontrolès visuomene“. Remdamasis Michelio Foucault pasiūlyta distinkcija tarp disciplinos ir šiuolaikinėms visuomenèms būdingo laissez faire principo (kam vèliau bus vartojama biopolitikos samprata), Deleuze'as pastebi, kad pirmoji patyrẻ savotišką krizę, kuri davė akstiną formuotis tam, ką pats filosofas apibrěžia talpiu terminu „kontrolë“. Aprašydamas konceptualinę takoskyrą tarp disciplinos ir kontrolès, Deleuze'as pastebi, kad disciplinos ir kontrolès visuomenès skiriasi savo topologija, logika, formuojamomis subjektyvumo formomis bei galios technikomis ir technologijomis.

Pasak filosofo, disciplinos visuomenèse remiamasi institucine galia, kuri siekia formuoti vadinamąsias „uždaras vietas“ (Deleuze 2012: 272): kalëjimus, ligonines, fabrikus, mokyklas, pan. Savo ruožtu kiekviena erdvė suponuoja tam tikrą tapatybę qua subjektyvumo formą: kalinio, ligonio, darbininko, mokinio ir t. t. Tokią socialinę logiką būtų galima apibūdinti kaip stratifikacijos, arba pertrūkių, logiką: Deleuze'as rašo, kad disciplinos visuomenèse individas yra nuolatos verčiamas pradèti viską iš naujo (Deleuze 2012: 273), kitaip tariant, igauti vis naują tapatybę ir atlikti vis kitokị socialinị vaidmenị iš jam siūlomo riboto repertuaro. Kitas svarus disciplinos visuomenės aspektas - ypatingas dėmesys produktyvumui. Kadangi disciplinos visuomenès atsiranda kartu su gamybos kapitalizmu, pagrindinis disciplinavimo siekis yra produkuoti apibrèžtas normas atitinkančius subjektus, didinti juc produktyvumą ir tokiu būdu reprodukuoti status quo - ir taip ad infinitum. Tai leidžia suprasti, kodèl kaip technologinị disciplinos visuomenès modelị Deleuzéas pasirenka varomas energijos mašinas.

Priešingai nei disciplinai, kontrolei vykdyti nèra reikalingos nei reguliuojančios institucijos, nei konkrečios erdvės: pačia plačiausia prasme kontrolè yra atopi$n \dot{e}$, arba, tariant Deleuze’o žodžiais, kontrolè yra „laisvai pasklidusi“ (Deleuze 2012: 4), operuojanti atviroje aplinkoje. Disciplinai yra būdingi pertrūkiai, fazės, pakopos, tarpsniai, o kontrole yra apibrěžtina kaip tęstinè: užuot veikus bendros normos pagrindu, kontrole funkcionuoja kaip tinklinè aplinka, arba, skolinantis Deleuzeo terminą, kaip savotiškas asambliažas, kuriame heterogeniški elementai nuolatos sąveikauja tarpusavyje, veikia vienas kitą ir yra veikiami vienas kito. Asambliažo terminą pasirenku neatsitiktinai - kaip negalima išardyti asambliažo, išskaidyti jo $\mathfrak{i}$ atskirus komponentus, taip pat negalima sustabdyti ịtinklintos kontrolès: net jei vienas ar kitas kontrolès tinklo elementas ir nustoja funkcionuoti, kontrolè yra vykdoma toliau. Taip yra todèl, kad kontrolei vykdyti nereikia nei tapatybių, nei subjekto per se: viena svariausių Deleuze’o įžvalgų yra ta, kad konkrečius, fizinius 
kūnus turinčius individus kontrolès visuomenèje keičia dividai - paprastai tariant, duomenys apie individą, jo virtuali reprezentacija. Vertinant kontrolę iš šios perspektyvos, galima teigti, jog ji darosi kibernetine: kontrolès visuomenès tikslas nèra didinti jos narių produktyvumą, bet gaunant duomenis nustatyti ryšius tarp narių, formuoti tinklus ir valdyti juos.

Kaip tai yra daroma? Kaip vieną pagrindinių priežasčių, lėmusių disciplinos visuomenių evoliuciją ị kontrolès visuomenes, Deleuze’as ịvardija technologinị lūži: perejjimą nuo paprastų prie sudètingų mašinų. Nesunku nujausti, kad kontrolè turi mažai ką bendro su produktyviomis, energijos varomomis mašinomis - jas keičia sudètingos mašinos, arba kompiuteriai, kurie veikia algoritmų principu, taigi (beveik) autonomiškai. Komentuodamas Deleuze’o esė, Alexanderis Galloway'us pastebi, jog senosios Deleuze’o filosofemos - pavyzdžiui, kūno be organų arba rizomos - pasirodo kaip nebeadekvačios kontrolès visuomenès realijoms aprašyti. Būtent kompiuteris, pasak Galloway'aus, yra pagrindine filosofema, nusakanti kontrolès visuomenès logiką (Galloway 2012: 524). Viena vertus, ši Galloway’aus pastaba pabrèžia ypatingą „bendradarbiavimo“ tarp filosofijos ir medijų studijų poreiki, siekiant rasti atsakymą i klausimą, kaip viena kitą veikia kibernetinè ir materiali tikrovè ir kaip šioje poroje atsiranda trečiasis - kontrolès - elementas. Tačiau, antra vertus, ji nurodo î, savotiška prasme, konceptualinę lakūną abiejose disciplinose: kaip kalbèti apie kompiuterizuotą ir kibernizuotą kontrolès visuomenę, išvengiant tiek perdèto deskriptyvumo, tiek atsieto nuo empirinès tikrovès abstraktumo? Kaip atrasti bendrą vardiklį tarp šių trijų dèmenų?

Lentelè, vaizduojanti konceptualinę takoskyrą tarp disciplinos ir kontrolès

\begin{tabular}{|l|l|l|}
\hline & \multicolumn{1}{|c|}{ DISCIPLINA } & \multicolumn{1}{c|}{ KONTROLE் } \\
\hline Topografija & Uždaros erdvès & Laisva cirkuliacija \\
\hline Logika & Pertrūkiai & Tęstinumas \\
\hline Subjektyvumo formos & Subjektas & Dividas \\
\hline Disciplininis atitikmuo & Termodinamika & Kibernetika \\
\hline Technologinis modelis & Varomos energijos mašinos & Kompiuteriai \\
\hline
\end{tabular}

Šiame straipsnyje siūloma prieiga - konceptualizuoti kontrolę (bei kontrolès technologijas - tiek strategijų, tiek konkrečių medijų prasme) kaip biopolitini faktorių, o tai reiškia - ịvesti dar vieną - biologinị - demenị. Kaip, sekdama Tiziana Terranova, teigia Sandra Robinson, neįmanoma ignoruoti biologinio kontrolès aspekto, nes kontrolè atsiranda kaip „atsakas ị augančią žmonių daugybę (multitude of people), procesus, informaciją ir tinklų dalis, kurie turètų igalinti vykdyti kontrolę tèkmių viduje ir tarp jų, bei iš jų tinklo navigacinių taškų (waypoints)“ (Terranova 
2004: 41; Robinson 2016: 6). Rašydamas apie biopolitikos atsiradimą, Eugene’as Thackeris išsako panašią pastabą: jo nuomone, biopolitinè valdysena atsiranda kaip bandymas valdyti ir reguliuoti biologini objektą - gyvuosius daugius (living multiplicities) (Thacker 2011: 152). Galiausiai, vertinti kontrolę kaip biopolitikos strategiją (arba net invariantą ar sinonimą) leidžia ir paties Michelio Foucault (kaip biopolitikos termino pradininko) biopolitikos konceptualizavimas kaip „aplinkokūros meno" (environmentalité) (Foucault 2008: 260), kurị Foucault priešpriešina senosioms disciplinos paradigmoms. Šia prasme biopolitika nera apibrěžtina vien kaip gyvybės valdymo technologijų visuma, bet ją taip pat derètų suvokti kaip tam tikrą galių ekologiją, kurioje biogalia sąveikauja su skirtingais aplinką sudarančiais komponentais ir reguliuoja jų tarpusavio sąveikas. Tad iš esmès Deleuzeo aprašyta kontrolès paradigma yra biopolitinè.

Vis dèlto, ịvedus biologinị dèmenį, atsiranda dar viena konceptualinè ịtampa tarp imanentiškos, nuolat kintančios ir besipriešinančios kontrolei gyvybès ir šaltos, algoritmų principu veikiančios mašinos. Kaip medijuojantị terminą Thackeris siūlo konceptualinį naujadarą - biomedijas. Pasak Patricia’os T. Clough, biomedijos žymi konceptualinị lūžż tarp autopoetinio (reprodukuojančio save) kūno ir naujojo kūno modelio - biomedijuojamo kūno. Tad biomedijos suvoktinos kaip medijos, techniškai keičiančios kūno gebas, keisdamos jo materialinị informacinị substratą (Clough 2010: 208). Pirmoje straipsnio dalyje bus pristatytos biomedijų sampratos atsiradimo priežastys, jos prasminis turinys ir konceptualinės ribos, aptartos dvi biomediju interpretacijos - kaip „tamsiųjų medijų“ ir "pilkujų medijų“. Antroje dalyje bus méginama pažvelgti į biomedijas kritiškai, lokalizuojant jas biopolitikos kontekste, ir glaustai aptarti, kaip biomedijos virsta naujos biogalios formos - neurogalios ịrankiu. Galiausiai, paskutineje, trečioje, straipsnio dalyje bus pristatyti ir ịvertinti konceptualiniai ir praktiniai pasipriešinimo neigiamai biomedijų įtakai scenarijai.

\section{Biomedijos: nuo „tamsiụjų medijų“ epistemologijos prie „pilkųjų medijų" etikos}

Konceptualizuojant biomedijas, svarbu iškart nustatyti šios sampratos turinị: terminu „biomedijos“ nemėginama apibūdinti konkrečiu mediju (nors vienos medijos turi stipresnị biomedijinị poveikị nei kitos), bet veikiau ịkontekstinti ir paaiškinti tokią įdomią padètị ${ }^{1}$, kai medijos veikia biologinị matmenị - kūną - plačiąja prasme keisdamos jit, kaip šią sąveiką aprašo Patricia T. Clough, „kūno informacini

${ }^{1}$ Autoriaus manymu, apie biomedijas taip pat prasminga kalbẻti kaip apie konceptualinį ịrankị, leidžiantị stebèti, vertinti ir kritiškai reflektuoti biologinị medijų poveikio matmenį, ką ir daro visi straipsnyje nagrinèjami autoriai. 
substratą" bei tokiu būdu transformuodamos patị kūno materialumą (Clough 2010: 208). Akivaizdu, kad tokia prieiga reikalauja kitokių nei ịprastos kūno, materialumo, informacijos ir, galiausiai, pačiu medijų interpretacijos. Pats Thackeris veikale „Biomedijos“ (Biomedia) kalba apie jas kaip apie tokią (iš esmès filosofinę) situaciją, kai ilgą laiką klasikinejje filosofijoje gyvavusi dichotomija tarp kūno ir medijų, arba kūno ir mašinos (technikos) praranda savo prasmę (Thacker 2004: 14). Toliau aptarsiu tokios situacijos teorines-disciplinines biomediju prielaidas bei šios sampratos filosofines pasekmes.

Formuluodamas biomedijų sampratą, Thackeris pateikia tris šio naujadaro poreikị grindžiančias prielaidas. Pirmoji - paties kūno kaip medijos suvokimas. Filosofas sąmoningai nusigręžia nuo anatomistinių-organicistinių kūno sampratų, kurios traktuoja kūną kaip užsklęstą sistemą ir užbaigtą struktūrą. Tokiam filosofiniam diskursui yra būdingas, paties Thackerio žodžiais tariant, „nerimas dèl kūno“ (Thacker 2004: 6) - kartais latentinè, o kartais eksplicitiškai reiškiama baimé, kad išoriniai objektai (šiuo atveju - technologijos arba medijos) neigiamai veikia kūną ir pažeidžia jo tariamą holistiškumą. Trumpai tariant, kūnas nèra stabilus anatominis konstruktas, bet, priešingai, procesualus, dinamiškas ir nuolat kintantis darinys, tiek veikiamas jị supančios aplinkos, tiek sąveikaudamas su ja - ergo medija.

Antroji Thackerio minima prielaida - biologijos technologizavimas. Ši paradigminị lūži filosofas aiškina taip: anksčiau galiojusi (linijinio) ryšio tarp technologijos ir kūno "sąsajos“ (interface) (Thacker 2004: 6) metafora netenka savo prasmés; tokių disciplinų, kaip biotechnologijų, bioinžinerijos ar bioinformatikos, atsiradimas paskatino iš naujo ieškoti būdų šiam ryšiui konceptualizuoti. Šios disciplinos privertė panaikinti ontologinę priešpriešą tarp biologijos ir technologijos, nes, kaip taikliai apibūdina Thackeris, „,biologija „informuoja“ skaitmeniškumą (the digital), lygiai taip pat, kaip skaitmeniškumas "ikūnija“ (corporealizes) biologiją“ (Thacker 2004: 7). Apibrèžtame kontekste biomedijų samprata pasirodo kaip parankus tarpininkas, panaikinantis ankstesnę konceptualinę ịtampą; biomedijos leidžia performuluoti kūno sampratą, aptikti joje dvejopą ryšį, kuriame vienas dẻmuo nẻra redukuotinas ị kitą: viena vertus, kūnas yra suvokiamas kaip biologinis, arba biomolekulinis kūnas per se, antra vertus - kaip kūnas, kuri galima „kompiliuoti“ per vizualizavimą, modeliavimą arba duomenų rinkimą (Thacker 2004: 13). Būtent šioje tarpinëje pozicijoje (tarp biologinio skaičiavimo (biological computing) ir skaičiavimo biologijos (computational biology) $)^{2}$ būtų galima lokalizuoti biomedijas.

2 Žodžiai „computing“, „computational“ verčiami kaip „skaičiavimas“, „skaičiavimo“ dèl egzistuojančio, taip pat plačiai vartojamo bioinformatikoje termino - skaičiavimo sistemos (computational systems). Suprantama, kad „computing“ neapsiriboja vien tik skaičiavimu. Kaip alternatyvas būtų galima svarstyti algoritminę biologiją, informacinę biologiją (pagal analogiją su informacinėmis technologijomis). 
Galiausiai, paskutinè, trečioji, prielaida, išplaukianti iš pirmụjų dviejų ir pagrindžianti jas, yra kibernetikos ir gyvybès mokslų sintezè. Nors iš pirmo žvilgsnio šios dvi disciplinos atrodo negiminingos ir net nebendramatès, jas sieja vienas bendras terminas - informacija. Pačia bendriausia prasme, vystantis technologijoms, tiek genetinis kodas galëjo būti konvertuojamas ị vienetų ir nulių seką bioinformatikoje, tiek, vice versa, kompiuterinis kodas galëjo turèti tiesioginę įtaką biologiniams procesams bioinžinerijoje. Šiems procesams apibūdinti Thackeris vartoja iš Levo Manovicho pasiskolintą transkodavimo sąvoką, nurodančią ị dviejų heterogenišku medijų sistemų ar objektų konvertuojamumą (Thacker 2004: 8; 73). Transkodavimas yra pagrindinis biomedijų veikimo principas, nes jomis siekiama tiesiogiai arba netiesiogiai perprojektuoti (reengineer) ir perkurti (redesign) kūną (Thacker 2004: 10).

Būtent pastarasis aspektas, atrodo, reikalauja daugiausiai filosofinès refleksijos. Thackeris išverčia biomedijų problematiką $\mathfrak{i}$ filosofijos kalbą, apeliuodamas $\mathfrak{i}$ Barucho Spinozos pusiau retorinị klausimą „ką geba kūnas?“. Sekdami Thackeriu, turetume suvokti biomedijas kaip savotišką (technologiškai informuotą) bandymą iš naujo užduoti ši klausimą ir, atitinkamai, ieškoti naujų atsakymų. Kūnas kaip medija, kompiliuojamas kūnas, transkodavimas verčia suvokti kūno statusą konceptualiniame biomedijų lauke, kaip tai formuluoja pats filosofas, kaip „kūną daugiau nei kūną“. Biomedijuojamas kūnas yra procesualus, tad, Thackerio teigimu, paveiktas biomedijų ,atgal gaunamas kūnas nèra tapatus kūnui, kuris buvo iki tol“" (Thacker 2004: 6). Tokią kūno transformaciją galima aiškinti remediacija - sąvoka, kurią Thackeris skolinasi iš Richardo Grusino ir Jay’aus Davido Bolterio. Jie performuluoja pačią medijų sampratą, teigdami, kad medija yra ne (vien) tai, kas medijuoja, tarpininkauja, bet tai, kas remedijuoja - taigi perkuria (Grusin, Bolter 1999: 98). Remediacijos terminu žymima dinamika tarp dviejų biomedijų polių: imediacijos (kai medijos tarsi „dingsta“ iš horizonto ir nèra pastebimos ar tiesiogiai patiriamos medijuojamo kūno) ir hipermediacijos (kai kūnas yra prisotinamas medijų kuriamomis reikšmèmis, tampa jų investicijų locus).

Imediacijos ir hipermediacijos problematika toliau nagrinëjama esė „Tamsiosios medijos" (Dark Media), kur Thackeris bando pažvelgti i šias biomedijų poveikio ypatybes kaip ị epistemologinę problemą. Performuluodamas ir konceptualizuodamas biomedijas kaip „tamsiąsias medijas ${ }^{3 “}$, filosofas apibūdina aporišką biomedijų kaip tamsiųjų medijų mediacijos būdą, grindžiamą negatyvia arba anti-komunikacija, kaip ekskomunikacija: „dvigubą judesi, kai komunikacijos imperatyvas yra išreiškiamas kaip komunikacijos negalimybe்“ (Thacker 2014: 80). Skirtingai nuo

3 „Tamsiosios medijos“ nèra biomedijų rūšis ar porūšis; veikiau biomedijų konceptualizavimas kaip „tamsiųjų medijų“ nurodo ị neatsietinas nuo jų epistemologines (pažinimo ir supratimo) problemas. 
komunikacijos, kuri yra semiotinè (naudojami simboliai, kuriamos reikšmės, perduodamos žinutes), ekskomunikacija yra, bent jau tradicine prasme, asemiotinè; tad Marshallo McLuhano postulatas apie konvencionalias medijas - „medija yra žinute்" - virsta ị Thackerio siūloma tamsiųjų medijų formulę: „daugiau nebebus jokių žinučių“ (Thacker 2014: 80). Šioje formuleje užkoduotas tam tikras ,antihumanizmas“ (Thacker 2014: 86), nes (bio)medijavimo procesas nebẻra grindžiamas subjekto kognityvinèmis gebomis kurti ar dekoduoti žinutes, bet taikosi ị pati kūną, jo afektyvius, nesąmoningus ar pasąmoningus registrus, kontingentišką biologiją. Kitaip tariant (prie to dar grị̌siu kitame skyriuje), užuot veikusios subjektą (kategorija, kuri, biomedijų atveju, yra perteklinè), jos veikia kūno materialumą. Bet tai anaiptol nereiškia, kaip jis įspejja, kad medijos yra „sugedusios“, priešingai, „jos veikia per gerai - taip gerai, kad iš esmès mediacija vyksta lygmenyje, kuris yra anapus tradicinių žmogiškosios mediacijos formų“ (Thacker 2014: 129). Vertinant epistemologiškai, šis tamsusis biomedijų aspektas verčia susimąstyti apie ,juodosios dèžès" problematiką: nors biomedijų atveju gan aiški ịvestis ir išvestis, negalime atsekti, stebèti ir suprasti tarp šių dviejų fazių vykstančio medijavimo proceso. Kitaip tariant, išliekant Spinozos iškelto „ką geba kūnas?“ klausimo rèmuose, negalime artikuliuoti, kokias transformacijas patiria mūsų kūnas, ir, apskritai, ar mūsų kūnas yra patyręs transformaciją. Tad Thackeris reziumuoja: „medijos yra gyviausios (ergo - biomedijos - pastaba mano, D. P.) būtent tą akimirką, kai jos yra mažiausiai pasiekiamos" (Thacker 2014: 140).

Thackerio pasiūlytą „,tamsiụjų medijų" konceptą būtų galima gretinti su „pilkujų mediju“" samprata, kurią formuluoja Matthew Fulleris ir Andrew Goffey knygoje Blogosios medijos (Evil Media). Tačiau Thackerị labiau domina šiuolaikinių (bio)medjų infrastruktūros epistemologinès dilemos, o Fulleris ir Goffey sutelkia daugiau dèmesio ị jos etinị aspektą. Inspiruoti Primo Levi „pilkosios zonos" sąvokos, autoriai apibūdina pilkąsias medijas kaip tokias, kurių veikimo principas yra „etiškai dviprasmiškas, kurių ribos yra prastai apibrěžtos, o vidinė struktūra - sudètinga" (Fuller, Goffey 2012: 11). Taigi pilkosios medijos yra sinonimiškos nepastebimoms kasdienèms mediacijoms. Autorių teigimu, šiuolaikinèje ekonomikoje (kurią jie apibūdina kaip informacijos ekonomiką) pilkosios medijos yra savotiškas ịstatymas, „kodifikuojantis skirtingas elgesio formas tarp savęs ir kitų darinių, kurio pasekmè - išoriškai standartizuotų elgesio formų kūrimas" (Fuller, Goffey 2012: 131). Būtent šis aspektas leidžia tapatinti pilkąsias medijas su biomedijomis: Fulleris ir Goffey apibrèžia pilkumą kaip šiuolaikinio socialinio pasaulio „afektyvią ir percepcinę salygą" (Fuller, Goffey 2012: 12); kitaip tariant, medijos (per)konfigūruoja kūniškus afektus, potyrius ir būsenas: „malonumas, baimè, technologinis entuziazmas, švelniai hipnozinè euforija, bjaurūs jausmai ir paranojinis pyktis yra 
sąlygojami objektų ir objektyvių formų, kurie sudaro jų (medijų - pastaba mano, D. P.) aplinką“, rašo autoriai.

Šios afektyvios manipuliacijos gali būti vertinamos ne tik iš etinès, bet taip pat ir iš estetinès perspektyvos, kaip teigia patys medijų teoretikai. Jų ịsitikinimu, „yra estetika, kuri yra neatskiriama bei neatsiejama nuo technologijų, technikų, praktikų ir įrenginių, sudarančių šiuolaikinių visuomenių abstrakčias infrastruktūras“ (Fuller, Goffey 2012: 13). Etinis, išverstas ì politinị biomedijų aspektas bus toliau probleminamas kitame skyriuje, pristatant kritinę Patricia'os T. Clough biomediju interpretaciją. Estetinis, arba biomedijų dizaino, aspektas bus aptartas, analizuojant originalią Warreno Neidicho neurogalios koncepciją.

\section{Biomedijos kaip biopolitikos simptomas:}

nuo biomedijuojamo kūno prie prefrontalinès žievès valdymo

Medijų teoretikè, feministė Patricia T. Clough praplečia biomedijų kaip „tamsiųjų“ ir "pilkujjų“ medijų paradigmą, ịvesdama ị ją (bio)politinę dimensiją. Savo monografijoje Vartotojo pasamone: apie afektą, medijas ir mata (The User Unconscious: On Affect, Media, and Measure) ji teigia, kad „kompiuterinès technologijos, neoliberalizmas, biopolitika vis dar skverbiasi į žmogaus subjektyvumo ir socialumo ontologinius pagrindus“ (Clough 2018: ix). Remdamasi Deleuze’o „kontrolès visuomenių“ konceptualine eksplikacija bei ankstesniame skyriuje aptarta anti-anatomistine kūno samprata, Clough sieja neoliberalios biopolitinès galios infrastruktūrą su nauju kūno modeliu, tampančiu pagrindiniu kontrolès taikiniu. Senąsias galios formas atitinkantị kūną kaip organizmą (kurị Clough apibrèžia kaip autopoetinị) keičia „kūnas kaip mašininis asambliažas, kur „mašininis“ nereiškia nei „mechanicistinis“, nei „organizminis“, bet veikiau atitinka afektyvumo, srovių ir energijos tèkmių materialumą“ (Clough 2018: 76). Toks kūnas, pasak Clough, yra šiuolaikinio biokibernetinio kapitalo investicijų vieta (Clough 2018: 77).

Kadangi būdvardis „biokibernetinis“ aiškiai suponuoja tiek biologinį, tiek technologini komponentus, apie medijų teoretikès aprašomą kūną yra prasminga kalbėti kaip apie biomedijuojamą kūną. Svarbu suvokti kontekstą, kuriame atsiranda tokia kūniškumo konfigūracija. Kaip minèta, informatikos-kibernetikos požiūriu, disciplinos ancien régime apibūdintinas kaip autopoetine sistema, kuri kuria save pačią per reprodukciją. Šios sistemos kūniškumo modelis yra organizmas, kurị su sistema sieja linijinis arba pusiau deterministinis santykis (kūnas yra formuojamas sistemos). Priešingai, naujasis režimas, kurị Clough bei kitos feministès ịvardija kaip techno-onto-post-biologinị (kuris yra sinonimiškas Deleuzéo aprašytai kontrolei), yra sietinas su atviromis sistemomis. Tokios sistemos yra nelinijinès, 
nes nėra įmanoma nusakyti vienos sistemos poveikio kitai per priežastinị ryši, nedeterministinès, nes tiesioginis poveikis nèra galimas, ir, galiausiai, metastabilios, taigi - dinamiškos ir nuolat kintančios. Tomis pačiomis kategorijomis galima apibūdinti ir atvirose sistemose atsirandantị kūno modelį - biomedijuojamą kūną, kuris yra nusakomas per tai, „ką geba daryti kūnas - jo afektus - o tai savo ruožtu nurodo i politines-ekonomines ir teorines investicijas ị materijai būdingą saviorganizaciją, arba materijos gebą būti informacinei, suteikti kūnui formą" (Clough 2018: 207-208).

Clough teigimu, biomedijos yra iššūkis kūno-kaip-organizmo autopoetiškumui (Clough 2018: 208), nes jos keičia pati jo informacijos substratą ir eksploatuoja jo virtualias gebas. Teoretizuodama virtualumą, Clough remiasi Deleuzeo, o, tiksliau tariant, jo interpretatoriaus - Briano Massumi - virtualumo samprata. Massumi, kaip ir Deleuze'as, panaikina (tariamą) priešpriešą tarp aktualumo (to, kas realizuota, manifestuota) ir virtualumo, vertindamas šias dvi plotmes kaip skirtingais būdais jutimui prieinamus ontologinius modusus. Jis apibrèžia virtualumą kaip „tai, kas yra maksimaliai abstraktu, bet tikra; ko tikrovė yra grynas potencialumas“ (Massumi 2002: 58). Massumi koncepcijoje "portalas“ $\mathfrak{i}$ virtualumą yra afektai - kūno gebos veikti ir būti paveiktam. Clough pabrèžia afektyvaus matmens svarbą, suvokiant, kaip veikia šiuolaikinès biomedijos. Biomedijos tarsi techniškai įrèmina afektą, paveikdamos kūno „metastabilumą“ ir tokiu būdu brèždamos tai, ką, skolindamasi Massumi metaforą, Clough vadina „kūno perspektyvomis“ (Clough 2010: 209). Kaip vyksta kūno perspektyvų brèžimas? Katherine Hayles pateikia tris kūno perspektyvų vektorius: somatinius atsakus, taktilinị grịžtamąji ryši ir kognityvines veiklas (Hayles 2006: 138), kuriuos apibendrintai būtų galima suvokti kaip afektyvią ortopediją.

Kritiškai reflektuodama Thackerio jžzvalgas apie biomedijas, Clough pastebi, kad, nors filosofui ir pavyko nužymèti biomedijų (bio)politinę ekonomiją (pavyzdžiui, jis aptaria koreliaciją tarp diagnostinių testų ir šių testų vartotojų duomenų rinkimą (Thacker 2004: 55-56)), jis vis dèlto yra linkęs suvokti kūną kaip organizmą (autopoetinę sistemą), o ne kaip nuolatos biomedijuojamą kūną (atvirą sistemą). Clough kelia kritinị klausimą: kaip biologiniai kūno duomenys virsta (bio)kapitalu? Jos ịsitikinimu, tarpinis terminas, kurị visiškai ignoruoja Thackeris, yra kūno afektai. Afektai, kaip aiškina Clough, yra ịrašyti i „,vaizdų cirkuliaciją, kuri sužadina jau patenkintą norą, jau išpildytą paklausą, nes kapitalas pasisavina vertę iš afekto" (Clough 2010: 220-221). Kitaip tariant, afektai - atviros biomedijuojamo kūno sistemos produktai - medijuojami taip, kad būtų kuo labiau prognozuojami ir kuo parankesni ekonomiškai. Tokioje biopolitinejje konfigūracijoje biomedijuojamas kūnas, kaip teigia Clough, yra „dirbantis kūnas“ (Clough 2010: 215). İdomu tai, kad, 
priešingai nei disciplinos visuomenėse, kurios rèmèsi aiškiomis subjektyvumo formomis (kaip jau aptarta jzžangoje, darbininko, mokinio, ligonio, pan.), (bio)politinės ekonomijos finkcionavimui subjekto kategorija yra pertekliné. „Afektyvūs kūnų pajègumai [...] suvokiami kaip tokie be subjekto, net be individo kūno, o tai leidžia ịsigalèti kontrolès ir politinio reguliavimo biurokratinèms procedūroms populiaciju gyvybès saugumo srityje“ (Clough 2010: 222), - aiškina Clough. Tai reiškia, kad šiuolaikinè (bio)politinè ekonomija remiasi „pažeidžiamumo biologija“ - kai ištisos populiacijos yra pažeidžiamos ne tik ligų, gyvybès ar mirties požiūriu, bet taip pat darosi priklausomos nuo valstybinių ir tarptautinių politinių sprendimų šiose srityse (Clough 2010: 223).

Ar ịmanomas pasipriešinimas tokiai totalizuojančiai biomedijų ịtakai? Clough pagrịstai pastebi, kad imanentiškas kūnui potencialumas yra, viena vertus, autopoezès paneigimas, o, antra vertus, naujos biopolitinès paradigmos taikinys. Tačiau ši naujoji (bio)politinė ekonomija nèra biomedijuojamo kūno priežastis - veikiau jo radimosi sąlyga. Nors dabartinè neoliberali santvarka eksploatuoja afektą - „jo atvirumą, netikètą radimąsi (emergence), kūrybingumą (Clough 2010: 224) - Clough ispeja, kad tiesioginis afekto santykis su virtualumu veikia dvejopai. Vadinasi, virtualumas visada išlieka pasipriešinimo pažadu.

Išties originalią biopolitikos ir biomedijų sąsajos konceptualizaciją siūlo medijų teoretikas ir menininkas Warrenas Neidichas straipsnyje „Kognityvinis kapitalizmas ir prefrontalinès žievès valdymas“ („Cognitive Capitalism and the Governance of the Prefrontal Cortex") Jis ịveda "neurogalios“ terminą, siekdamas pabrèžti kognityvinę-afektyvią šiuolaikinės biopolitikos dimensiją. Neidichas apibrèžia neurogalią kaip „biogalios tipą, kuris, užuot normalizavęs ir valdęs populiacijas ir kūnus, mobilizuoja smegenis ir sąmonę, produkuodamas tobulesnị nei kada nors egzistavusị globalųji vartotoją ir pilietị“ (Neidich 2017: 188). Žodžiu „vartotojas“ Neidichas nusako individą, vartojantį ne tik materialius produktus, bet, kognityvinio kapitalizmo kontekste, informaciją, mokẻdamas ne tiek pinigais, kiek savo dėmesiu. Žvelgiant iš šios perspektyvos, Neidicho idejja atliepia Fullerio ir Goffey aprašytą „informacijos ekonomiką“, kurią igalina šiuolaikinès (bio)medijos. Kaip ir Clough, Neidichas kalba apie mentalinị-kognityvinị, arba afektyvų, darbą, ypatingą dėmesị skirdamas neurofiziologiniam šio darbo aspektui: jei, Clough teigimu, afektų cirkuliacija leidžia formuoti receptyvų biogaliai biomedijuojamą kūną, Neidichas išverčia afekto sampratą i neurobiologijos kalbą, teigdamas, jog neurogalia formuoja „neuronų architektūrą" (Neidich 2017: 187).

Neurogalios konceptas pasirodo kaip itin parankus, norint konceptualizuoti šiuolaikinès biopolitikos veikimo principą, panaikinant ịtampą tarp biologijos, filosofijos ir medijų studijų. Pagrindinè Neidicho tezė yra ta, kad neurogalia veikia 
somatiškai, aktyvuodama konkrečią smegenų dali - prefrontalinę žievę. Ši smegenų dalis, be daugelio kitų funkcijų, yra atsakinga už emocijas, trumpalaikị dèmesí, ilgalaikį problemų sprendimą ir prisitaikymą prie aplinkos. Neidicho neurogalios koncepto teorinė atrama yra Catherine’os Malabou neuroplastiškumo samprata, kuri suponuoja kūno, sąmonès ir subjekto triados plastiškumą, taigi - dinamiškumą, procesualumą ir situatyvumą. Remiantis Massumi įžvalga, kad tarp kūniško potyrio ir sąmoningo šio potyrio suvokimo yra pusès sekundès trukmès intervalas (Massumi 2002: 29), galima teigti, kad neurogalia kaip tik ịsiterpia ị tą tarpsnị tarp percepcijos ir veiksmo (Neidich 2017: 192), stimuliuodama ne tik tam tikras reakcija ar poelgius, bet ir formuodama ịpročius. Aprašydamas šiuolaikinę neurokapitalizmo infrastruktūrą, medijų teoretikas pabrěžia, kad joje ypač svarbų vaidmenị atlieka farmacija, vartotojų elgsenos mokslai, programinė įranga (software agents) ir eksperimentiniai specialieji efektai (Neidich 2017: 191). Kitaip tariant, neurogalia veikia kaip afektu paskirstymas ir perskirstymas.

Kaip veikia šis perskirstymas biomedijų atveju? Neidichas pastebi tendenciją, kad šiuolaikinėms medijoms yra būdinga ypatinga „vizualinè ir kognityvinè ergonomika“ (Neidich 2017: 191), kuri yra kuriama atsižvelgiant ì žmogaus kognityvinį-sensorini aparatą. Ši ergonomika yra konvertuojama i ekonomiką, nes medijos projektuojamos tokiu būdu, kad patrauktų, išlaikytų ir išnaudotų vartotojų dèmesį, o tai yra pagrindinè „valiuta“ virtualioje erdvejje. Tai nėra lengva užduotis, nes, kaip pastebi Neidichas, dabartinị medijų landšaftą galima apibūdinti kaip „sensorinę-vizualinę anarchiją" (Neidich 2017: 195). Tam, kad sensorinėje-vizualinejje anarchijoje būtų galima pritraukti vartotojo dèmesį, yra kuriami „traukos asambliažai“. Traukos asambliažai apibūdintini kaip heterogeniški dariniai, kurie veikia skirtinguose lygmenyse (medijiniame, audiovizualiniame, lingvistiniame, fiziologiniame, psichologiniame, ir pan.), ir kurių pagrindinė paskirtis yra formuoti dèmesio vektorius (panašius ị Clough aprašytas „kūno trajektorijas“), kurie verčia smegenis "pažiūrèti ir ịsiminti“ (Neidich 2017: 195). Vienas iš traukos asambliažų fokalinių taškų yra dizainas kaip vizualinių elementų visuma, determinuojanti vartotojo patirtị. Vartotojo sąsajos ir patirties dizainas (UI / UX Design, User Interface / Experience Design) yra neatsiejamai susijęs su vartotojo patirties algoritmizavimu, adaptyvumu ir prediktyvumu, o tai leidžia neurogaliai naviguoti atvirose metastabiliose sistemose, kuriose tiesioginis poveikis nèra įmanomas. Tad neurogalia pradeda veikti ne aktualumo, bet, ką jau pastebejo Clough, potencialumo plotmèje. Neidichas vadina tokią algoritmizuotą infrastruktūrą "prognostine tvarka“: jis aiškina, kad algoritmai performuluoja „ateities sąlygas kaip tokias, kurios yra pasirenkamos ir uždaros. Tai paneigia idejją, kad ateitis yra tai, kas yra nežinoma“ (Neidich 2017: 196). 
Dar vienas svarus neurogalios aspektas - skatinti dopamino išskyrimą. Dopaminas, konvencionaliai žinomas kaip malonumo arba laimès hormonas, taip pat yra tiesiogiai susijęs su dèmesiu ir atmintimi, nes jis verčia intensyviau dirbti neuronus prefrontalinèje žievèje, kur jo koncentracija yra keturgubai didesné, palyginus su kitomis smegenų zonomis (Neidich 2017: 190). Kadangi Neidichas susieja neurogalią su prefrontalinès žievès valdymu biomedijų pagalba, ji taip pat gali versti kūną patirti teigiamus afektus, o tai, savo ruožtu, reiškia, kad kūnas pripažista neurogalios siūlomas malonumo formas kaip savo malonumo formas. Čia vèlgi galima pastebèti straipsnio pradžioje artikuliuotą lūžị tarp senụjų galios formų - disciplinuojančiu, ribojančių, baudžiančių - ir naujosios: produktyvios, skatinančios, suteikiančios malonumo. Tad prasminga užklausti, kokiais būdais būtų galima priešintis biomedijų pagalba vykdomai kontrolei, nukreiptai ne ị subjektą, o ị jo kūną, smegenis ir afektus?

\section{Anapus biomedijų: „nekomunikacijos vakuolès“ ir „blogosios medijos“}

Grižžnt prie Clough pasiūlytos biomedjuojamo kūno definicijos, virtualumas, prieigą prie kurio turi bet kokia atvira sistema, visada išlieka atsvara totalizuojančiai kontrolei. Imanentiškas kūnui produktyvumas, afektyvumas (reiškiantis, kad kūnas ne tik gali patirti afektus, bet ir veikti pats), vitališkumas aiškiai suponuoja neatsiejamą nuo kūno rezistencinę galią. Panašią pastabą išsako Deleuze’as, teigdamas, jog, kai galia pradeda taikytis i gyvybę, pati gyvybè pradeda jai priešintis (Deleuze 2006: 92-93). Antra vertus, Andrew Culpas veikale Tamsusis Deleuzéas (Dark Deleuze) savais žodžiais atliepia Galloway’aus pastabą: šiuolaikinè kontrolès paradigma sèkmingai integravo $\mathfrak{i}$ save pamatinius Deleuzeo filosofijos principus ir veikia pagal juos. Afirmatyvus Deleuze’o filosofijos skaitymas, kaip pagrịstai pastebi Culpas, turi tamsiąją pusę, kurią deliozininkai yra linkę ignoruoti; jie ne visada atsižvelgia ị tai, kad „afektai yra valdomi tironų, molekulinės revoliucijos paverčiamos fašistinèmis, o nomadinès karo mašinos yra ịtraukiamos ị kovą už valstybę" (Culp 2016: 13). Ši pastaba yra ypatingai svarbi biomedijų kontekste, juk, kaip aptarta, jos taikosi ì psichosomatinius registrus ir formuoja biogaliai palankų kūną ne drausdamos, ribodamos, ar ịbaugindamos, bet produkuodamos, motyvuodamos elgtis biogaliai parankiais būdais ir atsilygindamos už tokị elgesį.

Vadinasi, viena vertus, skatinamas biogalios produktyvumas gali būti ịveiktas pasitelkiant savo tiesioginę priešpriešą - neproduktyvumą. Tokią rezistencijos liniją būtu galima sąlygiškai apibrèžti kaip negatyvią. İdomu, kad ją plètoja pats Deleuze’as. Interviu su Negri, aptardamas, kaip galima ištrūkti iš viską apiman- 
čios kontrolès spąstų, filosofas atkreipia dèmesị ị imanentiškai komunikacijai (ir su ja neišvengiamai susijusiam medijavimui) būdingą problemiškumą. Derètų suvokti, jog medijos kaip komunikacijos formos, pirmiausia ir svarbiausia, yra ne techninès, bet socialinès - o tai reiškia, kad jos yra tiesiogiai priklausomos nuo socialinio, politinio ir ekonominio konteksto, kuriame jos randasi. Deleuze’as ịspéja, kad dabartiniame kontekste komunikacija yra „korumpuota“, tad, atrodo, vienintelis pasipriešinimo priverstiniam komunikacijos imperatyvui būdas yra „kurti nekomunikacijos vakuoles" ir "grandinès pertraukiklius“ (Deleuze 1990). Tai yra Deleuze’o filosofijos tamsusis aspektas, kurị išryškina Culpas: kurti ne jungtis, bet disjunkciją, ne įsitraukti, o pasitraukti, galiausiai, ne komunikuoti (implikuojant lotynišką žodžio communus reikšmę - „bendras“), bet slèptis ir išlaikyti tylą. Tariant Thackerio žodžiais, toks anti-komunikacijos modelis leistų paversti biopolitiką $\mathfrak{i}$ jos inversiją - nekropolitiką, suvoktą kaip sveiko ir vientiso politinio kūno irimą (Thacker 2011: 154).

Antra vertus, galima pagrịstai teigti, jog toks pesimistinis rezistencijos scenarijus kultivuoja solipsistinį eskapizmą, kuriam pačiam norètųsi priešintis ir ieškoti kitokių būdų ịveikti biomedijų kontrolę. Tad kaip antrą rezistencijos liniją aptarsiu kritinę. Vartodamas kritikos sąvoką, turiu omenyje ne pasyvią ar reaktyvią kritiką, užimančią transcendentinę (anapus) poziciją kritikuojamo objekto atžvilgiu, bet Massumi siūlomą imanentišką kritiką. Filosofas aiškina, kad imanentiška kritika „keičia pačias radimosi (emergence) sąlygas. Užuot vertinusi tapsmą, ji įsitraukia ị jit“ (Massumi 2015: 71). Kaip tokị ịsitraukimo būdą galima vertinti Fullerio ir Goffey plètojamą „blogụjų medijų“ (evil media) konceptą, kuris, viena vertus, yra epistemologinis naujos medijų teorijos projektas, o, antra vertus, etiné-politinè strategija, veikianti Massumi siūlomu imanencijos principu.

Fulleris ir Goffey kritiškai reflektuoja senąji Google (kaip vienos reprezentatyviausių kontrolès paradigmoje veikiančių korporacijų) šūkị „Nebūkite blogi“ („Don’t be evil“). Kas šiame kontekste yra blogis? Medijų teoretikai grindžia savo blogio sampratą filosofo Jeano Baudrillard’o izžvalgomis. Pastarojo teigimu, šiuolaikiniame socialiniame-politiniame klimate medijos formuoja „gerą“ subjektą, kuris pasižymi tokiomis savybemis, kaip „infantilizmu, hiperkonformizmu, visiška priklausomybe, pasyvumu, idiotiškumu" (Baudrillard 1983: 107), tad gèris pasirodo ne kaip transcendentalinė, universali vertybè, bet kaip sisteminis (bio)galios aparato produktas. Vertinant šiuo aspektu, blogis yra šio priverstinio gèrio imperatyvo atmetimas, atsisakymas būti sistemos dalimi. Tad blogis, užuot prisitaikęs prie status quo, apnuogina slepiamą esančios sistemos antagonizmą ir kultivuoja jị. Tai nèra maištas per se, nors galima įžvelgti ir pastarojo elementų; veikiau blogis atskleidžia tai, kas yra imanentiškai neatsiejama nuo bet kurios sistemos, jos vidinius prieš- 
taravimus, skirtumus ir trūkius, kuriuos pati sistema bando užmaskuoti. Kaip tai realizuojama medijų studijose?

1. Bypass Representation

2. Exploit Anachronisms

3. Stimulate Malignancy

4. Machine the Commonplace

5. Make the Accidental the Essential

6. Recurse Stratagems

7. The Rapture of Capture

8. Sophisticating Machinery

9. What is Good for Natural Language is Good for Formal Language

10. Know your Data

11. Liberate Determinism

12. Inattention Economy

13. Brains Beyond Language

14. Keep Your Stratagem Secret As Long as Possible

15. Take Care of the Symbols, The Sense Will Follow

16. The Creativity of Matter

Stratagemų sąrašas (paimta iš Jussi Parikka tinklaraščio: https://jussiparikka.net/2011/06/14/do-some-evil/)

Fuller ir Goffey siūlo konkrečias stratagemas - taktikas, panaikinančias ịtampą tarp medijų teorijos ir praxis, nukreiptas $\mathfrak{i}$ (arba prieš) partikuliarias medijų praktikas, žinių korpusus ir institucijas (Fuller, Goffey 2009: 141). Paprastai tariant, stratagema yra reaktyvi strategija, kontrtaktika, kuria siekiama pergudrauti oponentą. „Blogosios medijos" kaip atsvara manipuliatyvioms biomedijoms kuria rezistencijos infrastruktūras, kurios sabotuoja ịprastą (bio)medijų veiklą. Kadangi medijų teoretikai siūlo net šešiolika stratagemų, būtų sudètinga jas visas išsamiai aptarti. Todèl pamėginsiu bent punktyriškai nužymèti pagrindinius stratagemų vektorius. „Blogụjų mediju“ studijos skatina atsisakyti reprezentacijos (panašiai, kaip Deleuze’as kalbejjo apie „grandinès pertraukiklius"), nepasikliauti ịprasta simboline tvarka, ne tik žinoti ir valdyti savo duomenis, bet ir sąmoningai juos keisti ir iškreipti, išlikti nedèmesingiems dèmesio ekonomikoje, veikti nenuspẻjamai ir spontaniškai, galiausiai, nuolatos „perdirbinèti“ savo stratagemas ir laikyti jas paslaptyje.

Nesunku pastebèti, kad kiekvienas šiu vektorių iš esmès nurodo tą pačią kryptị - veikti priešingu būdu nei to reikalauja biomediju modus operandi. Svarbu suvokti, kad tai yra algoritmizuotos struktūros, užprogramuotos veikti neapibrèžtomis sąlygomis - tačiau vargu ar jos geba nustatyti ir pakeisti šias sąlygas; ir, nors jos yra besimokančios (self-learning) bei adaptyvios, arba, Thackerio teigimu, „veikia pernelyg gerai“, tai toli gražu nereiškia, kad jų veikimas yra tobulas, o ju neįmanoma sabotuoti. Triukšmas, piratavimas, užkrètimas virusais yra, kaip rašo 
Deleuze’as „Prieraše apie kontrolès visuomenę", potencialūs pavojai nenuilstamai veikiančiai, laisvai pasklidusiai kontrolei. Performuluojant Fullerio ir Goffey stratagemas ị Deleuzéo filosofinę kalbą, biomedijoms, kurios nuolat reteritorizuoja - dèmesị, potyrius ir jausmus, afektus ir kūniškas gebas - ir paverčia juos kapitalu, reikia priešintis totalia deteritorizacija: kreatyviu chaosu, iš kurio neišvengiamai atsiranda skrydžio - arba pabėgimo - linijų. Metaforiškai tariant, tapti „virusu“, sukeliančiu pavojų „tobulai“ veikiančiai sistemai, jos tariamam integralumui. O tai reiškia tapti blogiu biomedijų (eko)sistemoje, kuri funkcionuoja per gerai.

Gauta 2021-07-04

Priimta 2021-09-30

\section{Literatūra}

Baudrillard, J. 1983. In The Shadow of the Silent Majorities... or the End of the Social, translated by P. Foss, P. Patton, J. Johnston. NYC: Columbia University.

Clough, P. 2010. “The Affective Turn: Political Economy, Biomedia, and Bodies”, in Gregg, M., and Seigworth, G. (eds.). The Affect Theory Reader. Durham \& London: Duke University Press, p. 206-225.

Clough, P. 2018. The User Unconscious: On Affect, Media, and Measure. Minneapolis: University of Minnesota Press.

Culp, A. 2016. Dark Deleuze. Minneapolis: University of Minnesota Press.

Deleuze, G. 1990. "Conversation with Antonio Negri" (Interview), translated by M. Joughin, Futur Anterieur, Spring, No. 1. Prieiga per internetą: https://www.generation-online. org/p/fpdeleuze3.htm [žiūrèta 2021-05-27].

Deleuze, G. 2012. „Prierašas apie kontrolès visuomenę“, in Deleuze, G. Derybos. 1972-1990. Vertė N. Milerius, L. Perkauskyte, A. Žukauskaite. Vilnius: Baltos lankos, p. 272-280.

Deleuze, G., Parnet, C. 2006. Dialogues II, translated by H. Tomlinson, B. Habberjam. New York, London: Continuum.

Foucault, M. 2008. The Government of Self and Others: Lectures at the College de France 19821983, translated by G. Burchell. New York: Palgrave Macmillan.

Fuller, M., and Goffey, A. 2009. "Toward an Evil Media Studies", in Parikka, J., and Sampson, D. (eds.). The Spam Book: On Viruses, Porn, and Other Anomalities. NYC: Hampton Press, p. 141-159.

Fuller, M., and Goffey, A. 2012. Evil Media. Cambridge: The MIT Press.

Galloway, A. 2012. “Computers and the Superfold”, Deleuze Studies, 6 (4): 513-528.

Grusin, R., and Bolter, J. 1999. Remediation: Understanding New Media. Cambridge: The MIT Press.

Hayles, K. 2006. "Traumas of Code", Critical Inquiry, 33 (1): 136-157.

Massumi, B. 2002. Parables for the Virtual: Movement, Affect, Sensation. Durham \& London: Duke University Press.

Massumi, B. 2015. Politics of Affect. Cambridge: Polity.

Neidich, W. 2016. "Cognitive capitalism and the governance of the prefrontal cortex", in Prozorov, S., and Rentea, S. (eds.) The Routledge Handbook of Biopolitics. London \& New York: Routledge, p. 187-204.

Petrina, D. 2021. "Affect Trapped: Algorithms, Control, Biopolitical Security", in Wrobel, S., and Skonieczny, K. (eds.). Living and Thinking in the Postdigital World: Theories, Experiences, Explorations. Warsaw: UNIVERSITAS, p. 219-234.

Robinson, S. 2016. "The Vital Network: An Algorithmic Milieu of Communication and Control", Communication $+1,5$, article 5: 1-22. 
Terranova, T. 2004. Network Culture: Politics for the Information Age. London: Pluto Press. Thacker, E. 2004. Biomedia. Minneapolis: University of Minnesota Press.

Thacker, E. 2011. "Necrologies, or the Death of the Body Politics", in Clough, P., and Willse, C. (eds.). Beyond Biopolitics: Essays on the Governance of Life and Death. Durham \& London: Duke University Press, p. 139-163.

Thacker, E. 2014. "Dark Media”, in Gallloway, A., Thacker, E., and Wark, M. (eds.). Excommunication: Three Inquiries in Media and Mediation. Chicago \& London: The University of Chicago Press, p. 77-151.

\section{Denis Petrina}

\section{BODILY MEDIATION: BIOMEDIA IN THE CONTEMPORARY SOCIETY OF CONTROL}

\section{Summary}

The aim of this article is to present, discuss and critically reflect the emerging in media studies notion of biomedia, which refutes the alleged dichotomy between technology and the body. In the broadest sense, biomedia can be construed as a particular way of mediation whereby the media directly affect and transform the biological dimension of the body and vice versa. The article opens with the discussion of the context in which biomedia emerge - the societies of control (G. Deleuze). In the this first part, the genesis of the concept of biomedia is discussed, as well as two conceptual paradigms - epistemological (E. Thacker's "dark media”) and ethical (M. Fuller, A. Goffey's "gray media") are presented. In the second part, the nexus between biomedia and the cyberbiopolitical regime is highlighted, as well as a peculiar form of biopower, functioning through biomedia - neuropower (W. Neidich) is presented. Ultimately, two potential resistance lines (negative and critical) are examined.

KEYWORDs: biomedia, "dark media”, "gray media”, biopolitics, control. 